the Internet is overtaking television as the public's main source of science news. This means that a larger global audience can now access, on demand, a great diversity of science coverage from media outlets around the world. Moreover, the public are no longer just passive consumers of information. The Internet is now the first place people go to look for more information on a scientific topic, such as stem cells or climate change. Thanks to the Internet, in short, one could argue that the overall state of science communication is better now than at any time in the past.

Yet there is no reason to be complacent. As the media industry moves online, some shakeout is inevitable. Straight news is becoming a commodity, which will be dominated by fewer players. Independent science desks and media can have a future in this environment, but only if they move up the food chain and provide proactive, deeper, must-read analyses instead of me-too articles reacting to the latest press releases.

In that context, perhaps the most worrisome finding in the Pew report is that this type of resource-intensive science coverage is precisely the most threatened: as the newspaper industry responds to falling circulation with sweeping cuts, science desks are among the first to suffer.
Media executives should pause to rethink these cuts to science desks and coverage on two counts. One is that this choice is often influenced by the widespread notion that science is of comparatively little interest to readers. According to Pew Center data, however, around two-thirds of all those who search online for news are after science and health news - second only to the weather - with technology coming third, ahead of politics and business. That trend is confirmed in reports published this past December by the European Commission.

Another, and more important, reason to sustain high-quality science journalism is that, in this context as much as any other, the media have a responsibility (with rewards in audience response) to fulfil their watchdog role. Many contemporary societal issues are both science-related and complex. Science reporters are essential for keeping tabs on government at every level, ensuring that decisionmakers listen to the best experts and scientific evidence available. They should also be in the front line of countering the misrepresentation of science, whether by anti-science groups, multinational corporations, or politicians - or indeed, by scientists and their institutions hyping their own work to gain fame and funding.

\title{
A reprogramming rush
}

\section{Stem-cell research is in danger of falling foul of haste.}

$\mathrm{n}$ the most recent of his series of stunning articles on induced pluripotent stem (iPS) cells (T. Aoi et al. Science doi:10.1126/science.1154884; 2008), Shinya Yamanaka made a couple of small mistakes. Happily, he has since given plausible explanations for the mistakes, and has effectively argued that they do not affect the article's central conclusions - thus heading off worries (and one unsubstantiated accusation) that the errors signalled deeper problems with the article.

Still, the incident illustrates why there is cause for concern as scientists hop on the iPS bandwagon (see page 406). The very existence of such carelessness by the leading light of iPS cell research, a scientist known for his thorough, careful work, shows how much the race mentality has taken over the field. The paper was published online a mere five and a half weeks after it was submitted. Other key articles in the field show similar signs of being rushed for publication. One biotech company recently announced its iPS cell results without even bothering to publish (see Nature 452, 132; 2008). And authors have been pushing journal editors to speed up peer review - under the threat of taking the paper elsewhere - which puts even more pressure on the small circle of reviewers sufficiently versed in iPS cell science.

Competition is good. Indeed, it is a major reason why iPS cell research has flourished since 2006, when Yamanaka first showed that a handful of genes can reprogram a cell to a pluripotent state. Nonetheless, the fast-moving fields of science are showing some unpleasant tendencies. Researchers are cutting corners and making mistakes. They are making over-hyped promises that will probably be broken. And they are neglecting other valuable fields of research. All this has already been seen in iPS cell research.

Hype may also carry researchers away from their mission and raise the spectre of fraud. Indeed, as Alan Trounson, head of the California Institute of Regenerative Medicine in San Francisco recently told Nature Reports Stem Cells, "excessive" media attention on iPS cell research could "separate science from reality" in the same way it did during the therapeutic-cloning scandal surrounding South Korea's Woo Suk Hwang. "Cool heads and a close connection with the lab should prevail in order to ensure science progresses truly by reliable evidence," he says.

The errors in Yamanaka's article are unfortunate - not least because they play into the hands of those who want to tarnish the science or the scientists. The criticism of Yamanaka's article came from an anonymous source who seemed bent on a personal attack. From the address "Reprogrammer Yamanaka" on 29 February, the e-mailer sent an account of Yamanaka's mistakes to journal editors, science journalists and scientists, scolding Yamanaka for his "embarrassing inconsistencies" and calling on him "to either retract their paper or provide meticulous and thorough new analysis".

Yes, this attack was overly dramatic. And yes, Yamanaka owned up to his mistakes with commendable speed and honesty. But even so, this incident should be a wake-up call.

Post-Hwang, scientists and journals undertook much soul-searching about what went wrong. Some came to the bad-apple theory - that Hwang was just an anomaly. Most, rightly, saw it as a deeper problem that could affect any field of science. In the aftermath, many researchers vowed to redouble their efforts to guard against honest mistakes (usually attributed, as Hwang did at first, to the rush to submit articles), as well as against the whole spectrum of selective presentation of data, manipulation of images and outright fraud. iPS cell research may be the first substantial test of these efforts. 